\title{
Molecular survey and genetic characterization of tick-borne pathogens in dogs in metropolitan Recife (north-eastern Brazil)
}

\author{
Rafael Ramos • Carlos Ramos • Flábio Araújo • Renato Oliveira • Ingrid Souza • \\ Danillo Pimentel • Mariana Galindo • Marilia Santana • Eduardo Rosas • \\ Maria Faustino $\cdot$ Leucio Alves
}

Received: 4 December 2009 / Accepted: 8 July 2010 /Published online: 3 August 2010

(C) Springer-Verlag 2010

\begin{abstract}
To identify DNA of the main tick-borne pathogens in dogs from Recife (Brazil), polymerase chain reactions were carried out on blood samples of dogs treated at the Veterinary Hospital of the Universidade Federal Rural de Pernambuco from March 2007 to June 2008. The detection of DNA was performed using specific primers. Amplicons were analyzed through electrophoresis and sequencing. A phylogenetic tree was constructed using the UPGMA method, revealing that the sequences were closely related to those of strains from other geographic regions. Among the 205 blood samples analyzed, $48.78 \%$ was positive for Anaplasma platys; $38.04 \%$ was positive for Ehrlichia canis; $7.31 \%$ was positive for Babesia canis vogeli; and $0.49 \%$ was positive for Hepatozoon canis and Mycoplasma haemocanis. Coinfection of two or three pathogens was found in $23.9 \%(49 / 205)$ of the dogs. The subspecies $B$. canis vogeli was identified. Infection by $H$. canis and M. haemocanis is reported for the first time in dogs in the state of Pernambuco (Brazil). The data indicate that the main tick-borne pathogens in dogs in this region are E. canis and/or A. platys, followed by $B$. canis vogeli.
\end{abstract}

R. Ramos $\cdot$ C. Ramos $\cdot$ D. Pimentel $\cdot$ M. Galindo $\cdot$ M. Santana $\cdot$

E. Rosas $\cdot$ M. Faustino $\cdot$ L. Alves $(\bowtie)$

Department of Veterinary Medicine,

Universidade Federal Rural de Pernambuco,

Recife, Pernambuco, Brazil

e-mail: leucioalves@hotmail.com

F. Araújo $\cdot$ R. Oliveira $\cdot$ I. Souza

Area de Sanidade Animal,

Empresa Brasileira de Pesquisa Agropecuária,

Campo Grande, Mato Grosso do Sul, Brazil

\section{Introduction}

Vector-borne diseases are increasingly recognized as the cause of severe clinical illness in dogs (Solano-Gallego et al. 2006). In Brazil, the main tick-borne pathogens described for dogs are Babesia canis, Ehrlichia canis, Anaplasma platys, Hepatozoon canis, and Mycoplasma haemocanis (Passos et al. 2005; Santos et al. 2007; Forlano et al. 2007; Trapp et al. 2006). The transmission of these pathogens occurs mainly by the brown dog tick, Rhipicephalus sanguineus (Labruna and Pereira 2001; Dantas-Torres et al. 2004).

B. canis and Babesia gibsoni are the etiological agents of canine babesiosis. The former is the most important in Brazil and is divided into three subspecies (Babesia canis canis, Babesia canis vogeli, and Babesia canis rossi), which are characterized by vector, geographical distribution, pathogenicity, and antigenic property (Uilenberg et al. 1989). At present, only B. canis vogeli (Passos et al. 2005) and B. gibsoni (Trapp et al. 2006) have been described infecting dogs in Brazil. In the genus Hepatozoon, two species have been described infecting dogs, H. canis and Hepatozoon americanum (Baneth et al. 2000). However, only $H$. canis has been described in Brazil, based on molecular studies (Rubini et al. 2005; Forlano et al. 2007). E. canis and A. platys are obligatory intracellular rickettsia with tropism for leukocytes and platelets, respectively. Both have wide geographical distribution (Aguirre et al. 2006; Pinyoowong et al. 2007; Yabsley et al. 2008) and are the main blood pathogens that infect dogs in urban areas in Brazil (Santos et al. 2007). There is little epidemiological information on M. haemocanis in Brazil (Trapp et al. 2006).

In the routine of veterinary clinics, the microscopic examination of stained blood smears and serological 
methods have been used for the diagnosis of many of these pathogens. However, the cyclic parasitemia of many of these organisms (Harrus et al. 1997) and serologic cross-reactivity between related species (Dreher et al. 2005) hinder the diagnosis of these infections (Ferreira et al. 2007).

The aims of the present study were to assess the frequency of infection by $B$. canis vogeli, A. platys, $E$. canis, M. haemocanis, and Hepatozon canis in sick dogs using a molecular tool and to molecularly characterize the strains of the tick-borne pathogens found.

\section{Materials and methods}

Biological samples and DNA extraction

Blood samples from 205 dogs from metropolitan Recife (state of Pernambuco, Brazil) treated at the Veterinary Hospital of Universidade Federal Rural de Pernambuco from March 2007 to June 2008 were collected with EDTA and stored at $-20^{\circ} \mathrm{C}$. Genomic DNA was extracted using the Easy DNA kit (Invitrogen) following the manufacturer's instructions. The quality and concentration of the extracted samples were evaluated through electrophoresis in agarose gel and spectrophotometry. Positive controls were obtained from dogs having tested positive in microscopic blood smear examination. Distilled water was used as negative controls.

\section{DNA amplification}

The detection of pathogen DNA was performed with polymerase chain reaction (PCR) using a sets of primers (Table 1). A single PCR was used for the detection of $B$. canis vogeli, Hepatozoon sp., and Mycoplasma sp., and a nested PCR was used for E. canis and A. platys. The reactions were performed in final volume of $25 \mu$, containing $10 \mathrm{mM}$ of Tris- $\mathrm{HCl}(\mathrm{pH} 8.3), 50 \mu \mathrm{M}$ of $\mathrm{KCl}$, $1.5 \mathrm{mM}$ of $\mathrm{MgCl}_{2}, 0.2 \mathrm{mM}$ of each desoxynucleoside triphosphate, 1.5 U of Taq DNA polymerase (Invitrogen), 11 pmol of each primer, and approximately $100 \mathrm{\eta g}$ of genomic DNA. The following parameters were used in the single PCR: $94^{\circ} \mathrm{C}$ for $3 \mathrm{~min}$, followed by 30 cycles at $94^{\circ} \mathrm{C}$ for $1 \mathrm{~min}$, annealing at $56^{\circ} \mathrm{C}$ for B. canis and B. gibsoni, $50^{\circ} \mathrm{C}$ for Mycoplasma sp. and Hepatozoon sp. for $30 \mathrm{~s}$, extension at $72^{\circ} \mathrm{C}$ for $40 \mathrm{~s}$. In the nested PCR, the primer sets used in the first reaction were $8 \mathrm{~F}$ and $1448 \mathrm{R}$ for $A$. platys and ECC and ECB for E. canis. In the second reaction, the PLATYS-F and EHR16S-R primer sets were used for A. platys, and the HE and ECA primer sets were used for E. canis. The PCR parameters were $94^{\circ} \mathrm{C}$ for $1 \mathrm{~min}$, followed by 35 cycles at $94^{\circ} \mathrm{C}$ for $1 \mathrm{~min}$, annealing at $45^{\circ} \mathrm{C}$ for $A$. platys and $60^{\circ} \mathrm{C}$ for E. canis for $1 \mathrm{~min}$, extension at $72^{\circ} \mathrm{C}$ for $40 \mathrm{~s}$. In the second reaction, the annealing temperature was $53^{\circ} \mathrm{C}$ for $A$. platys and $60^{\circ} \mathrm{C}$ for E. canis for $30 \mathrm{~s}$. A final extension step at $72^{\circ} \mathrm{C}$ for $3 \mathrm{~min}$, prior to stopping the reaction at $4^{\circ} \mathrm{C}$, was employed for all reactions. The amplification products were viewed under an ultraviolet light after electrophoresis on agarose gel stained with SyBr Gold (Invitrogen).

To avoid cross-contamination and sample carryover, pre- and post-PCR sample processings were performed in separate rooms. All fluid transfers were carried out with plugged pipette tips to eliminate aerosols.

\section{Sequence analysis}

Amplicons were purified from agarose gel using the QIAEX II Gel Extraction Kit (Qiagen) and sequenced in both directions using the BigDye Terminator v3.1 Cycle Sequencing Kit in an ABI 3130 Genetic Analyzer (Applied

Table 1 Primers used in PCR for detection of DNA of tick-borne pathogens in dogs from metropolitan region of Recife, Pernambuco state, Brazil

\begin{tabular}{|c|c|c|c|c|c|}
\hline Primer & Pathogen & Gene & Sequence $5^{\prime}-3^{\prime}$ & Base pairs & Reference \\
\hline $\begin{array}{l}8 \mathrm{~F} \\
1448 \mathrm{R}\end{array}$ & A. platys & 16S rRNA & $\begin{array}{l}\text { AGTTTGATCATGGCTCAG } \\
\text { CCATGGCGTGACGGGCAGTGT }\end{array}$ & - & Martin et al. (2005) \\
\hline $\begin{array}{l}\text { PLATYS-F } \\
\text { EHR16S-R }\end{array}$ & A. platys & 16S rRNA & $\begin{array}{l}\text { GATTTTTGTCGTAGCTTGCTATG } \\
\text { TAGCACTCATCGTTTACAGC }\end{array}$ & 678 & Martin et al. (2005) \\
\hline $\begin{array}{l}\mathrm{ECC} \\
\mathrm{ECB}\end{array}$ & E. canis & $16 \mathrm{~S}$ rRNA & $\begin{array}{l}\text { AGAACGAACGCTGGCGGCAAGCC } \\
\text { CGTATTACCGCGGCTGCTGGC }\end{array}$ & 478 & Wen et al. (1997) \\
\hline $\begin{array}{l}\mathrm{HE} \\
\mathrm{ECA}\end{array}$ & E. canis & 16S rRNA & $\begin{array}{l}\text { TATAGGTACCGTCATTATCTTCCCTAT } \\
\text { CAATTATTTATAGCCTCTGGCTATAGGAA }\end{array}$ & 389 & Wen et al. (1997) \\
\hline $\begin{array}{l}\text { HepF } \\
\text { HepR }\end{array}$ & Hepatozoon sp. & 18S rRNA & $\begin{array}{l}\text { ATACATGAGCAAAATCTCAAC } \\
\text { CTTATTATTCCATGCTGCAG }\end{array}$ & 666 & Inokuma et al. (2002) \\
\hline $\begin{array}{l}\text { fHF5 } \\
\text { rHF6 }\end{array}$ & Mycoplasma sp. & 16S rRNA & $\begin{array}{l}\text { AGCAGCAGTAGGGAATCTTCCAC } \\
\text { TGCACCACCTGTCACCTCGATAAC }\end{array}$ & 659 & Messick et al. (1998) \\
\hline $\begin{array}{l}\text { BAB1 } \\
\text { BAB4 }\end{array}$ & B. canis vogeli & 18S rRNA & $\begin{array}{l}\text { GTGAACCTTATCACTTAAAGG } \\
\text { CAACTCCTCCACGCAATCG }\end{array}$ & 590 & Duarte et al. (2008) \\
\hline
\end{tabular}


Fig. 1 Phylogenetic tree based on Babesia (a) and Hepatozoon (b) 18S rRNA gene sequences. Sequences were compared with the UPGMA method operated by MEGA software (version 4.0). Scale bar represents the number of mutations per sequence position. The numbers at the nodes indicate the percentage of 500 bootstrap resamplings. New sequences are marked by arrows

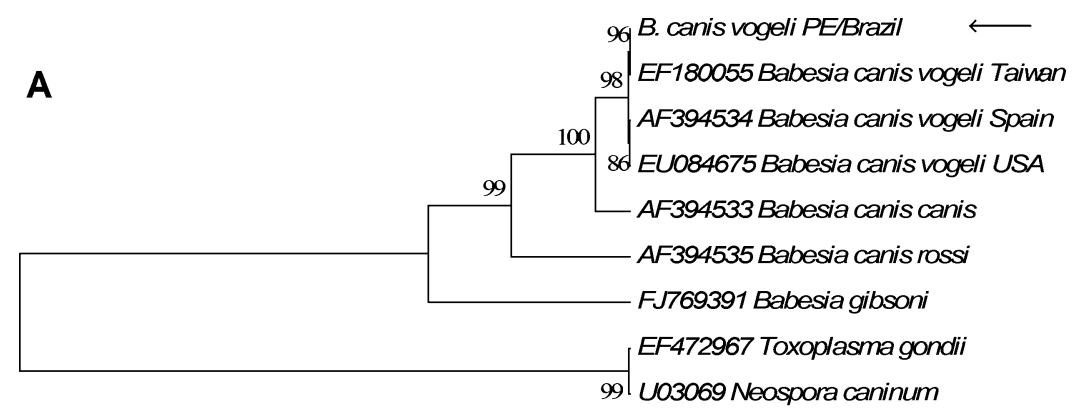

$\begin{array}{ccccc}1 & 1 & 1 & & \\ 2.0 & 1.5 & 1.0 & 0.5 & 0.0\end{array}$

B
Fig. 2 Phylogenetic tree based on Anaplasma, Ehrlichia, and Mycoplasma $16 \mathrm{~S}$ rRNA gene sequences. Sequences were compared with the UPGMA method operated by MEGA software (version 4.0). Scale bar represents the number of mutations per sequence position. The numbers at the nodes indicate the percentage of 500 bootstrap resamplings. New sequences are marked by arrows

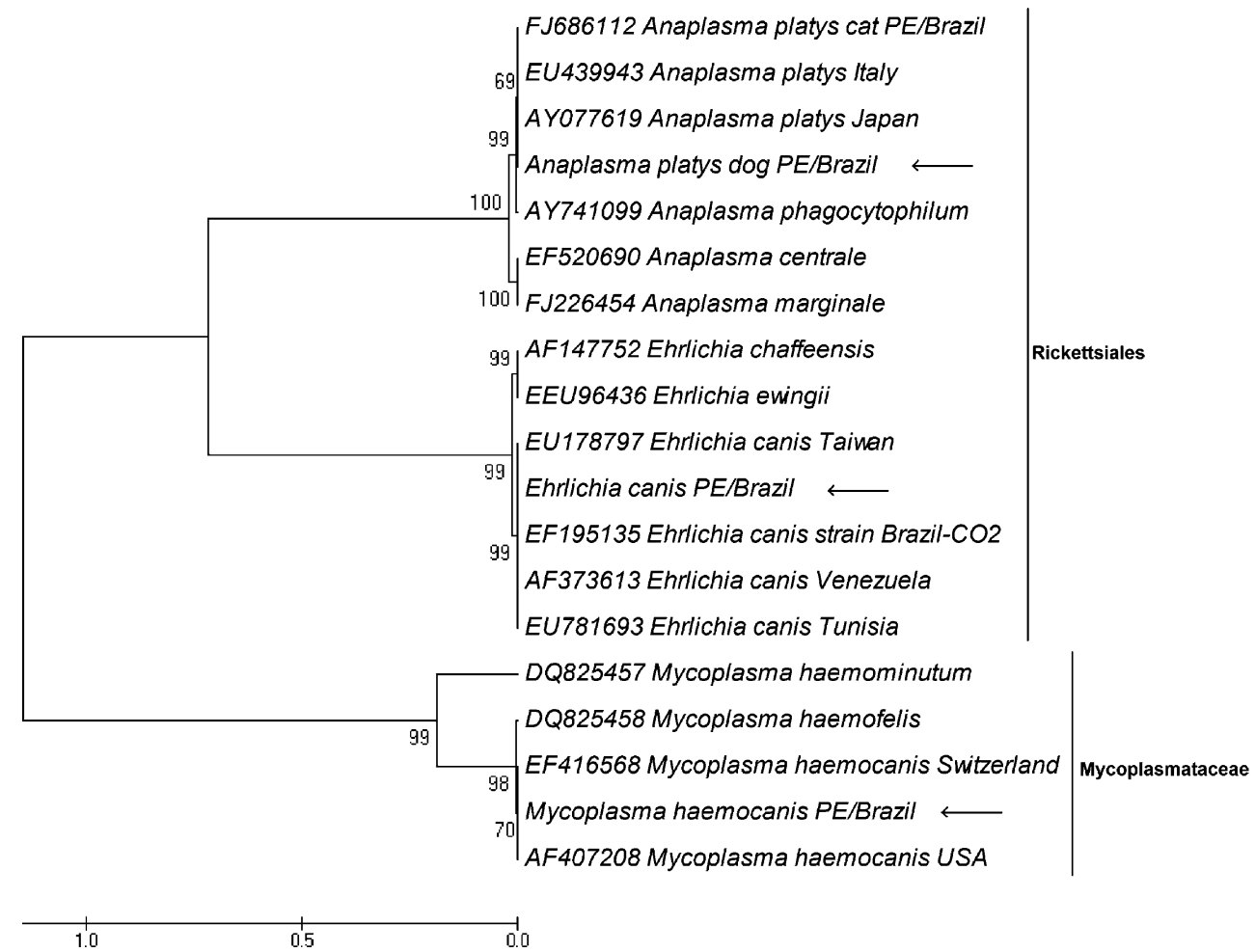


Table 2 Percentage of infections and coinfections between pathogens studied in dogs from metropolitan region of Recife, Pernambuco state, Brazil

\begin{tabular}{lclc}
\hline Infection & Percentage (\%) & Co-infection & Percentage (\%) \\
\hline A. platys & $48.78(100 / 205)$ & E. canis/A. platys & $16.09(33 / 205)$ \\
E. canis & $38.04(79 / 205)$ & E. canis/B. canis & $2.92(6 / 205)$ \\
B. canis vogeli & $7.31(15 / 205)$ & A. platys/B. canis & $1.95(4 / 205)$ \\
H. canis & $0.48(1 / 205)$ & A. platys/M. haemocanis & $0.48 \%(1 / 205)$ \\
M. haemocanis & $0.48(1 / 205)$ & A. platys/B. canis/E. canis & $1.95 \%(4 / 205)$ \\
& & A. platys/E. canis/H. canis & $0.48 \%(1 / 205)$
\end{tabular}

Biosystems). Five randomly selected $E$. canis, A. platys, and $B$. canis vogeli positive PCR products were sequenced. For Hepatozoon and Mycoplasma, only one animal was positive, and at least four distinct amplicons were sequenced.

Sequence chromatograms were evaluated and edited using the Sequencher v 4.1.4 program (Gene Codes), and consensus sequences were submitted to a BLASTn (Altschul et al. 1990) search (http://www.ncbi.nlm.nih.gov) to determine the sequence identity in order to find orthologous sequences available in the GenBank database. A phylogenetic tree was constructed using the UPGMA method (Sneath and Sokal 1973). The sequences used in this study for the construction of the phylogenetic tree were available in the GenBank database (Figs. 1 and 2). Bootstrap resampling (500 replicates) was performed for the statistical support of the reliabilities of the nodes on the trees (Felsenstein 1985) using the MEGA program, version 4.0 (Tamura et al. 2007).

\section{Results}

Table 2 displays the frequency of dogs positive for tick-borne pathogens in metropolitan Recife. In the DNA sequence analysis, the sequences were identical between the amplicons sequenced for each pathogen in this study. Specific identity of $99 \%$ to $100 \%$ was found between consensus sequence of local isolates and sequences that exhibited the highest level of homology in the BLASTn search (GenBank: E. canis EU178797, A. platys EU439943, B. canis vogeli $\mathrm{EF} 180055, M$. haemocanis $\mathrm{EF} 416568$, and $H$. canis FJ743476). Partial consensus sequences of the 16S rRNA gene (E. canis, A. platys, and M. haemocanis) and 18S rRNA gene (B. canis vogeli and $H$. canis) obtained in this study were deposited in the GenBank database under accession numbers FJ943579, FJ943580, FJ911910, FJ588003, and FJ943578, respectively (Table 3).

A subspecies-specific PCR using a primer set developed by Duarte et al. (2008) was successfully used in the present study for the diagnosis of $B$. canis vogeli, as confirmed by the sequence analysis. In the phylogenetic analysis of the partial 18S rRNA sequence from $H$. canis (Fig. 1), the PE/ Brazil isolate was grouped in a cluster with the isolates Curupira 1 (no. AY461376), Spain 1 (no. AY150067), and others, while isolates Venezuela 2 (no. DQ439540) and Spain 2 (no. AY461378) were grouped in an independent clade (Fig. 1b). The phylogenetic tree for B. canis vogeli (Fig. 1a), A. platys, E. canis, and M. haemocanis (Fig. 2) demonstrates that variability between Brazilian strain of these pathogens and those from other geographic regions is low. Coinfections of two or three pathogens occurred in $23.9 \%(49 / 205)$ of the animals (Table 2$)$. The most frequently coinfections were by $E$. canis and A. platys.

\section{Discussion}

The frequency of dogs positive for E. canis and A. platys is highly variable in different regions of the world. The percentage of positive animals in the present study- $A$. platys $(48.78 \%)$ and E. canis $(38.04 \%)$ - is higher than the $15.84 \%$ described by Ferreira et al. (2007) for A. platys in Rio de Janeiro (Brazil) and the $38.9 \%$ and $14.9 \%$ described by Santos et al. (2007) for E. canis and A. platys, respectively, in Ribeirão Preto (Brazil). It was also higher than that described for A platys by Huang et al. (2005; $16 \%$ ) in Venezuela and De La Fuente et al. $(2006 ; 4 \%)$ in
Table 3 Pathogen, specific identity, and GenBank accession number

\footnotetext{
${ }^{\text {a }}$ Sequence of GenBank accession numbers obtained in this study
}

\begin{tabular}{llll}
\hline Pathogen & Identity (\%) & Best hit & GenBank $^{\mathrm{a}}$ \\
\hline E. canis & 99 & E. canis (EU178797) & FJ943579 \\
A. platys & 99 & A. platys (EU439943) & FJ943580 \\
B. canis vogeli & 99 & B. canis vogeli (EF180055) & FJ588003 \\
M. haemocanis & 100 & M. haemocanis (EF416568) & FJ911910 \\
H. canis & 99 & H. canis (FJ743476) & FJ943578 \\
\hline
\end{tabular}


Sicily, Italy. However, the percentage in the present study is similar to that described by Wen et al. (1997) for E. canis in the USA (44\%).

According to Labarthe et al. (2003), approximately 20\% of dogs treated in veterinary hospitals and clinics in the southern, south-eastern, central-western, and north-eastern regions of Brazil are serologically positive for E. canis. The variation in the prevalence of infection may be related to differences in the dog population studied, geographical differences in vector exposure, and potential differences in the diagnostic methods employed (Solano-Gallego et al. 2006). In the present study, the high frequencies found were likely due to the fact that the dog population sampled was clinically suspected of having tick-borne diseases and that the test used (nPCR) has high sensitivity (Wen et al. 1997; Martin et al. 2005). The frequency of positive animals for B. canis vogeli $(7.31 \%)$ was higher than that described for Spain $(0.01 \%)$ and Sudan $(0.025 \%)$, as described by Oyamada et al. (2005). Amblyomma ticks have been implicated in the transmission of $H$. canis Curupira 1 and Spain 1, and $R$. sanguineus is implicated in the transmission of other isolates (Criado-Fornelio et al. 2007). This may explain the low frequency of positive dogs to $H$. canis in the present study $(0.48 \%)$, as the brown dog tick, $R$. sanguineus, has been the only species found parasitizing dogs in metropolitan Recife (Dantas-Torres et al. 2004).

In Brazil, canine hepatozoonosis is mainly reported in rural areas, where the main ticks are Amblyomma spp. (Labruna and Pereira 2001; Rubini et al. 2008). A recent molecular survey found $53.3 \%$ prevalence in dogs in the rural areas in the state of São Paulo (Rubini et al. 2008).

M. haemocanis, formerly classified as a Haemobartonella species, has recently been positioned within the genus Mycoplasma by 16S rRNA analysis (Messick et al. 2002). This group of bacteria attaches to the surface of red blood cells, where it then grows. Infection by $M$. haemocanis has been documented in dogs in the USA, Europe, Canada, the United Kingdom (Seneviratna et al. 1973; Chalker 2005), and Brazil (Trapp et al. 2006), although few epidemiological data are found. The PCR assay used in the present study was originally developed for the detection of Mycoplasma haemofelis in cats (Messick et al. 1998) and was later successfully used to detect $M$. haemocanis in a dog (Brinson and Messick 2001). This PCR assay can be used for the detection of other Mycoplasma species such as Candidatus Mycoplasma haemominutum and Candidatus Mycoplasma haematoparvum (Foley et al. 1998).

There are descriptions of co-infection by tick-borne pathogens of dogs in China (Hua et al. 2000), the Caribbean (Yabsley et al. 2008), Venezuela (Suksawat et al. 2001), and Brazil (Santos et al. 2007). The high prevalence of A. platys combined with $E$. canis is evidence that $R$. sanguineus may be the same vector for both. If $R$. sanguineus is a competent vector, A. platy is likely to be found in the same geographic areas as E. canis (Yabsley et al. 2008). The present study also presents the first description of infection by $H$. canis and M. haemocanis in dogs in the state of Pernambuco, Brazil.

\section{Conclusions}

The data from the present study indicate that the main tickborne pathogens of dogs in metropolitan Recife are E. canis and/or A. platys, followed by B. canis vogeli. These findings are important to the understanding of the epidemiology of tick-borne pathogens of domestic dogs in this region, which will assist in the management of these pathogens.

Acknowledgments The authors are grateful to the Brazilian fostering agencies Conselho Nacional de Desenvolvimento Científico e Tecnológico (CNPq) and Fundação de Amparo à Ciência e Tecnologia do Estado de Pernambuco (FACEPE) and EC (INCO 003691MEDLABAB).

\section{References}

Aguirre E, Tesouro MA, Ruiz L, Amusategui I, Sainz A (2006) Genetic characterization of Anaplasma (Ehrlichia) platys in dogs in Spain. J Vet Med 53:197-200

Altschul SF, Gish W, Miller W, Myers EW, Lipman DJ (1990) Basic local alignment search tool. J Mol Biol 215:403-410

Baneth G, Barta JR, Shkap V, Martin DS, Macintire DK, VincentJohnson N (2000) Genetic and antigenic evidence supports the separation of Hepatozoon canis and Hepatozoon americanum at the species level. J Clin Microbiol 38:1298-1301

Brinson JJ, Messick JB (2001) Use of a polymerase chain reaction assay for detection of Haemobartonella canis in a dog. J Am Vet Med Assoc 218:1943-1945

Chalker VJ (2005) Canine mycoplasmas. Res Vet Sci 79:1-8

Criado-Fornelio A, Buling A, Cunha-Filho NA, Ruas JL, Farias NA, Rey-Valeiron C, Pingret JL, Etievant M, Barba-Carretero JC (2007) Development and evaluation of a quantitative PCR assay for detection of Hepatozoon sp. Vet Parasitol 150:352-356

Dantas-Torres F, Figueiredo LA, Faustino MAG (2004) Ectoparasitos de cães provenientes de alguns municípios da região metropolitana do Recife, Pernambuco, Brasil. Rev Bras Parasitol Vet 13:151-154

De La Fuente J, Torina A, Naranjo V, Nicosia S, Alongi A, Mantia FL, Kocan KM (2006) Molecular characterization of Anaplasma platys strains from dogs in Sicily, Italy. Vet Res 2:01-05

Dreher UM, De La Fuente J, Hofmam-Lehmann R, Meli ML, Pusterla N, Kocan KM, Woldehiwet Z, Braun U, Regula G, Straerk KDC, Lutz H (2005) Serologic cross-reactivity between Anaplasma marginale and Anaplasma phagocytophilum. Clin Diag Lab Immunol 2:1177-1183

Duarte SC, Linhares GFC, Romanowsky TN, Silveira Neto OJ, Borges LMF (2008) Assessment of primers designed for the subspecies-specific discrimination among Babesia cani canis, Babesia canis vogeli and Babesia canis rossi by PCR assay. Vet Parasitol 152:16-20

Ferreira RF, Cerqueira AMF, Pereira AM, Guimarães CM, Sá AG, Abreu FS, Massard CL, Almonsny NRP (2007) Anaplasma 
platys diagnosis in dogs: comparison between morphological and molecular tests. Int J Appl Res Vet Med 5:113-119

Felsenstein J (1985) Confidence limits on phylogenies: an approach using the bootstrap. Evolution 39:783-791

Foley JE, Harrus S, Poland A, Chomel B, Pedersen NC (1998) Molecular, clinical and pathologic comparison of two distinct strains of Haemobartonella felis in domestic cats. Am J Vet Res 59:1581-1588

Forlano MD, Teixeira KRS, Scofield A, Elisei C, Yotoko KSC, Fernandes KR, Linhares GFC, Ewing SA, Massard CL (2007) Molecular characterization of Hepatozoon sp. from Brazilian dogs and its phylogenetic relationship with other Hepatozoon spp. Vet Parasitol 145:21-30

Harrus S, Aroch I, Lavy E, Bark H (1997) Clinical manifestations of infectious canine cyclic thrombocytopenia. Vet Rec 141:247-250

Hua P, Yuhai M, Shide T, Yang S, Bohai W, Xiangrui C (2000) Canine ehrlichiosis caused simultaneously by Ehrlichia canis and Ehrlichia platys. Microbiol Immunol 44:737-739

Huang H, Unver A, Perez MJ, Orellana NG, Rikihisa Y (2005) Prevalence and molecular analysis of Anaplasma platys in dogs in Lara, Venezuela. Braz J Microbiol 36:211-216

Inokuma H, Fujii K, Matsumoto K, Okuda M, Nakagome K, Kosugi R, Hirakawa M, Onishi T (2002) Demonstration of Anaplasma (Ehrlichia) platys inclusions in peripheral blood platelets of a dog in Japan. Vet Parasitol 110:145-152

Labruna MB, Pereira MC (2001) Carrapatos em cães do Brasil. Clin Vet 30:24-32

Labarthe NV, Pereira MC, Barbarini O, Mckee W, Coimbra CA, Hoskins J (2003) Serologic prevalence of Dirofilaria immitis, Ehrlichia canis, and Borrelia burgdorferi infections in Brazil. Vet Ther 4:67-75

Martin AR, Brown GK, Dunstan RH, Roberts TK (2005) Anaplasma platys: an improved PCR for its detection in dogs. Exp Parasitol 109:176-180

Messick JB, Berent LM, Cooper SK (1998) Development and evaluation of a PCR-based assay for detection of Haemobartonella felis in cats and differentiation of $H$. felis from related bacteria by restriction fragment length polymorphism analysis. J Clin Microbiol $36: 462-466$

Messick JB, Walker PG, Raphael W, Berent L, Shi X (2002) Candidatus mycoplasma haemodidelphidis $\mathrm{sp}$. Candidatus mycoplasma haemolamae sp. and Mycoplasma haemocanis haemotrophic parasites from a naturally infected opossum (Didelphis virginiana), alpaca (Lama pacos) and dog (Canis familiaris): phylogenetic and secondary structural relatedness of their 16S rRNA genes to other mycoplasmas. Int J Syst Evol Microbiol 52:693-698

Oyamada M, Davoust B, Boni M, Dereure J, Bucheton B, Hammad A, Itamoto K, Okuda M, Inokuma H (2005) Detection of Babesia canis rossi, B. canis vogeli, and Hepatozoon canis in dogs in a village of eastern Sudan by using a screening PCR and sequencing methodologies. Clin Diagn Lab Immunol 12:13431346
Passos LM, Geiger SM, Ribeiro MF, Pfister K, Zahler-Rinder M (2005) First molecular detection of Babesia vogeli in dogs from Brazil. Vet Parasitol 127:81-85

Pinyoowong D, Jittapalapon S, Suksawat F, Stich RW, Thamchaipenet A (2007) Molecular characterization of Thai Ehrlichia canis and Anaplasma platys strains detected in dogs. Infect Genet Evol 8:433-438

Rubini AS, Paduan KS, Cavalcante GG, Ribolla PEM, O’Dwyer LH (2005) Molecular identification and characterization of canine Hepatozoon species from Brazil. Parasitol Res 97:91-93

Rubini AS, Paduan KS, Lopes VVA, O’Dwyer LH (2008) Molecular and parasitological survey of Hepatozoon canis (Apicomplexa: Hepatozoidae) in dogs from rural area of São Paulo state, Brazil. Parasitol Res 102:895-899

Santos F, Coppede JS, Pereira ALA, Oliveira LP, Roberto PG, Benedetti RBR, Zucoloto LB, Lucas F, Sobreira L, Marins M (2007) Molecular evaluation of the incidence of Ehrlichia canis, Anaplasma platys and Babesia spp. in dogs from Ribeirão Preto, Brazil. Vet J 179:145-148

Seneviratna P, Weeasinghe N, Ariyadasa S (1973) Transmission of Heamobartonella canis by the dog tick, Rhipicephalus sanguineus. Res Vet Sci 14:112-114

Sneath PHA, Sokal RR (1973) Numerical taxonomy. Freeman, San Francisco, p 573

Solano-Gallego L, Lull J, Osso M, Hegarty B, Breitschwerdt E (2006) A serological study of exposure to arthropod-borne pathogens in dogs from northeastern Spain. Vet Res 37:231-244

Suksawat J, Pitulle C, Arraga-Alvarado C, Madrigal K, Hancock SI, Breitschwerdt EB (2001) Coinfection with three Ehrlichia species in dogs from Thailand and Venezuela with emphasis on consideration of $16 \mathrm{~S}$ ribosomal DNA secondary structure. J Clin Microbiol 39:90-93

Tamura K, Dudley J, Nei M, Kumar S (2007) MEGA4: molecular evolutionary genetics analysis (MEGA) software version 4.0. Mol Biol Evol 24:1596-1599

Trapp SM, Dagnone AS, Vidotto O, Freire RL, Amude AM, Morais HSA (2006) Seroepidemiology of canine babesiosis and ehrlichiosis in a hospital population. Vet Parasitol 140:223-230

Uilenberg G, Franssen FFJ, Perie M, Spanjer AMM (1989) Three groups of Babesia canis distinguished and a proposal for nomenclature. Vet Quart 11:33-40

Wen B, Rikihisa Y, Mott JM, Greene R, Kim HY, Zhi N, Couto GC, Unver A, Bartsch R (1997) Comparison of nested PCR with imunofluorescent antibody assay for detection of Ehrlichia canis infection in dogs treated with doxycycline. J Clin Microbiol 35:1852-1855

Yabsley MJ, Mckibben J, Macpherson CN, Cattan PF, Cherry NA, Hegarty BC, Breitschwerdt EB, Connor TO, Chandrashekar R, Paterson T, Perea ML, Ball G, Fiesen S, Goedde J, Henderson B, Sylvester W (2008) Prevalence of Ehrlichia canis, Anaplasma platys, Babesia canis, Hepatozoon canis, Bartonella vinsonii berkhoffi, and Rickettsia spp. in dogs from Grenada. Vet Parasitol 151:279-285 